\title{
ZOFIA HERTZ W ŚWIETLE KORESPONDENCJI Z OJCEM (1945-1958)
}

\author{
Kamila LABNO (Uniwersytet Pedagogiczny im. KEN, Kraków)
}

W Archiwum Instytutu Literackiego w Maisons-Laffitte zdeponowano pokaźny zbiór korespondencji Zofii Hertz z adresatami z różnych części świata. Pół wieku trwała wymiana listów ze współpracownikami „Kultury” (często w imieniu redaktora Jerzego Giedroycia), przyjaciółmi, prenumeratorami czy też z rodziną osiadłą w kraju.

W niniejszym artykule chciałabym pochylić się nad tymi listami, które pisała i otrzymywała od ojca, Ludwika Neudinga. Kolekcja ta, z lat 1945-1958, to bogaty zbiór listów, z których pierwszy datowany jest na 20 listopada 1945 roku (nadesłany po wojnie z Łodzi), ostatni zaś na 6 stycznia 1958 roku. Zachowało się 110 listów do Zofii Hertz, natomiast tylko jeden do Ludwika Neudinga — jest to zapewne nikły ślad całej korespondencji na linii Paryż-Łódź ${ }^{1}$. Zbiór ten jest zdecydowanie wart uwagi nie tylko ze względu na poruszane treści, ale i ukazanie innego, nieznanego dotąd obrazu Zofii Hertz. Lektura listów wzbogaca naszą wiedzę o jednym ze współzałożycieli Instytutu Literackiego, ukazując jednocześnie relację (bardzo typową jak na tamte czasy), zachodzącą pomiędzy emigrantem a pozostałą w kraju rodziną. Zyskuje ona przez to wymiar bardziej uniwersalny. Poddany działaniu cenzury list nigdy nie będzie swoją treścią przypominał tego pisanego w poczuciu braku zagrożenia ze strony władz reżimu. Naszą wiedzę wzbogaci dodatkowo korespondencja, zainicjowana w 1958 roku $^{2}$ po śmierci Ludwika Neudinga, pomiędzy Zofią Hertz (Paryż) a Eleonorą Neuding (Łódź), drugą żoną Ludwika. Zanim jednak przejdziemy do szczegółowego omówienia listów, wypada nam zapoznać się z sylwetkami korespondentów i określić w zarysie kontekst łączących ich relacji.

Zofia Hertz, córka Heleny z d. Nisenson i Ludwika Neudinga, przyszła na świat 27 lutego 1910 roku w Warszawie. Jej ojciec, urodzony w 1886 roku, pochodził ze spolonizowanej rodziny żydowskiej. Pisał: ,jestem Polakiem wyznania rzymskokatolickie-

\footnotetext{
${ }^{1}$ Archiwum Instytutu Literackiego, Spuścizna po Zofii Hertz (dalej: AIL 04), sygn. POZiH 04, Korespondencja z Ludwikiem Neudingiem (1945-1958).

${ }^{2}$ AIL, sygn. POZiH 05 (dalej: AIL 05), Korespondencja z Eleonorą Neuding (1958-1968).
} 
go”3. Ukończył Wyższą Szkołę Handlową przy Zgromadzeniu Kupców w Warszawie, pracował jako księgowy. Wspominał: „długoletnia praktyka w poważnych firmach w Warszawie i Łodzi dała mi możność dokładnego obznajomienia się z wszelakiemi czynnościami wchodzącemi w zakres biurowości i księgowości”’”. O Matce, Helenie, wiemy niewiele - tyle tylko, ile Zofia Hertz zdołała opowiedzieć podczas wywiadu z Izą Chruślińską:

Moi rodzice [...] pobrali się w 1907 roku w Warszawie, po trwającym kilka lat narzeczeństwie, gdyż rodzina mamy nie chciała zgodzić się na ślub. Nawet siostry ojca przekonywały mamę, aby się z nim nie wiązała. Ojciec nie był złym człowiekiem, miał jednak uzasadnioną opinię lekkoducha i nie nadawał się ani na męża, ani na ojca rodziny. Ale mama uparła się i postawiła na swoim. Niedługo po ślubie rodzice wyjechali do Wilna, urodził się mój brat, który zmarł na krup, jeszcze zanim ja się urodziłam. Rodzice wrócili do Warszawy. Ale ich małżeństwo nie układało się już najlepiej ${ }^{5}$.

Jak udało się ustalić Annie Olszewskiej, w archiwach wileńskich — w zachowanych księgach metrykalnych dla wyznań niechrześcijańskich ${ }^{6}$ - nie sposób znaleźć żadnych zapisów o rodzinie Neudingów.

Rodzice Zofii Hertz rozeszli się, gdy ta miała zaledwie cztery lata. Zofia z matką pozostały w Warszawie, zaś ojciec, jak wynika z ankiety personalnej z 1952 roku i wypunktowanego $\mathrm{w}$ niej przebiegu pracy zawodowej, wyjechał i podjął pracę $\mathrm{w}$ Łodzi ${ }^{7}$. Innych informacji na ten temat dostarcza wywiad Izy Chruślińskiej z Zofią Hertz: „Mój ojciec mieszkał wtedy w Piotrkowie, pracował tam jako urzędnik" ${ }^{\prime 8}$. Matka zachorowała na zapalenie płuc i zmarła przedwcześnie, gdy Zofia miała zaledwie osiem lat ${ }^{9}$. Zmuszona przez okoliczności, przerwała naukę $\mathrm{w}$ warszawskiej szkole dla panien Janiny Popielewskiej i Janiny Zdzienieckiej i zamieszkała w Łodzi u krewnych ze strony matki. Tam kontynuowała naukę w Gimnazjum Żeńskim Romany KonopczyńskiejSobolewskiej. Ojciec nie podjął się wychowania córki, ułożył sobie życie z inną kobietą — w 1924 roku wziął ślub z Eleonorą z domu Brenda (wg Olszewskiej) lub Kausik (wg ankiety pracowniczej) $)^{10}$. O drugiej żonie ojca nastoletnia wówczas Zofia dowie-

\footnotetext{
${ }^{3}$ Archiwum Krajowej Rady Spółdzielczej (dalej: AKRS), Akta pracownicze Ludwika Neudinga.

${ }^{4}$ AKRS, Życiorys Ludwika Neudinga (15 listopada 1952); w cytowanym fragmencie zachowano oryginalną pisownię.

${ }^{5}$ I. Chruślińska, Była raz Kultura... Rozmowy z Zofią Hertz, Lublin 2003, s. 15.

${ }^{6}$ A. Olszewska, Dokumenty Zofii Hertz (1910/1911-2003), Zeszyty Historyczne 2006 nr 156, s. 5.

${ }^{7}$ AKRS, Akta pracownicze Ludwika Neudinga, Ankieta Personalna, k. 4.

${ }^{8}$ I. Chruślińska, Była raz „Kultura”, s. 15-16.

${ }^{9} \mathrm{~W}$ rozmowie z Izą Chruślińską Zofia Hertz podaje, że miała osiem lat, kiedy jej matka zmarła. Jednak z akt szkoły wynika coś innego. Czytamy tam, że Zofia Hertz przerwała naukę w roku szkolnym 1920/1921, mając dziesięć-jedenaście lat. W Warszawie mieszkała do śmierci matki, a zaraz po tym przeniosła się do Łodzi, sądzę więc, że Helena Neuding zmarła nie wtedy, gdy Zofia miała osiem lat, a między dziesiątym a jedenastym rokiem jej życia; Archiwum m. st. Warszawy, Oddział Zamiejscowy w Milanówku (dalej: AMSTW), Indeks gimnazjum żeńskiego J. Popielewskiej i J. Zdzienieckiej, sygn. 3, k. 228.

${ }^{10}$ Nazwisko zapisane jest niewyraźnie, istnieje więc pewna trudność w precyzyjnym odczytaniu, wedle moich przypuszczeń wersja Kausik wydaje się prawdopodobna. Z drugiej jednak strony na kartce pocztowej z 26 grudnia 1958 roku Eleonora użyła nazwiska „Brenda”. Dlaczego więc Ludwik w ankiecie pracowniczej podał inną wersję? Może Eleonora była już wcześniej mężatką - nazwisko Kausik było po pierwszym mężu, zaś Brenda było jej nazwiskiem panieńskim, do którego wróciła po śmierci Neudinga.
} 
działa się przypadkiem, i to nie od Ludwika, ale od wujostwa ${ }^{11}$. Jak się później okazało, nie była to jedyna niemiła niespodzianka, jaka miała ją spotkać. Podczas jednej z wizyt w Piotrkowie, pod nieobecność ojca i macochy, do domu przyszła „starsza pani w kapeluszu" i wywiązał się dialog:

- Ma pani dobrego wujka, płaci za szkołę, opłaca wszystko.

- Jakiego wujka proszę pani?

- No, przecież panienka jest tu u swojego wujka.

— Nie, proszę pani. Ja tu jestem u Ojca!

- U ojca?

- Tak, u ojca.

- A to jest mama?

— Nie. Mama nie żyje ${ }^{12}$.

Nieznajoma doprowadziła nieświadomie do ujawnienia tajemnicy ojca: pozostawał wcześniej w związku małżeńskim, z którego miał córkę. Zofia Hertz rozumiała trudne, jak na tamte czasy, położenie Ludwika Neudinga, toteż nigdy nie miała do niego o to żalu. Jej relacje z macochą układały się poprawnie. Kontakty z ojcem nigdy nie były częste i ograniczały się do finansowego wsparcia czy odwiedzin od czasu do czasu. Zofia, zmuszona przez okoliczności, bardzo szybko się usamodzielniła.

W 1928 roku rozpoczęła studia na Uniwersytecie Warszawskim, na wydziale prawa, a już rok później była pracownikiem kancelarii notarialnej rejenta Apolinarego Karnawalskiego w Łodzi ${ }^{13}$. W 1938 roku wyszła za mąż za Zygmunta Hertza, dobrze zapowiadającego się syna łódzkiego przedsiębiorcy, późniejszego wieloletniego współpracownika Jerzego Giedroycia i mieszkańca domu w Maisons-Laffitte. Gdy wybuchła wojna, śladem swojego małżonka wyjechała na wschód, nb. nigdy już nie powróciła do Polski. W tym czasie nie utrzymywała kontaktów z ojcem, dialog ożył na nowo dopiero po wojnie.

Pierwszy nadesłany list z Łodzi, o którym wiemy, datowany jest na 20 lutego 1945 roku. Ludwik Neuding, nie kryjąc radości i wzruszenia, napisał w nim:

Dziś odwiedziła mnie siostra Twego męża i oznajmiła mi radosną nowinę, że żyjecie i jesteście zdrowi. Nie mogę Ci Zosiu wypowiedzieć mej radości. Całe 5 lat myślałem o Tobie, gdzie się poniewierasz i jak sobie radzisz w tych ciężkich warunkach. Wyobrażam sobie coście przez ten okres musieli przechodzić - szczęście, że to wszystko jest już za nami - i jesteście żywi i zdrowi ${ }^{14}$.

Już wtedy Ludwik wiedział, że córka wybrała emigrację. Pozostawał w kontakcie z siostrą Zygmunta, Anielą, która raz na jakiś czas informowała go o ich losach.

Jak wynika z dalszej części przytaczanego listu, rodzina Neudingów została ciężko doświadczona przez los podczas wojny. Wielu bliskich znajomych i przyjaciół zginęło w obozach w Polsce i w Niemczech. Mimo iż Ludwik Neuding nie odniósł się w ogóle do swoich przeżyć z okresu wojny, to jednak z ankiety personalnej wiemy, że został wysiedlony ze swojego łódzkiego mieszkania, a Eleonora, jego druga żona, była więźniarką obozu w Łodzi. W tym czasie ojciec Zofii prowadził w miarę spokojne życie (na ile to było możliwe, zważywszy na okoliczności), mieszkał w Łodzi, gdzie pracował w prywatnych firmach. Między pierwszym zachowanym listem a drugim

\footnotetext{
${ }^{11}$ H. M. Giza, Ostatnie lato w Maisons-Laffitte, Wrocław 2007, s. 134-136.

${ }^{12}$ Tamże, s. 136-137.

${ }^{13}$ Akta kancelarii notarialnej rejenta Apolinarego Karnawalskiego zdeponowane są w Archiwum Państwowym w Łodzi.

${ }^{14}$ AIL 04, list Ludwika Neudinga do Zofii Hertz z 20 lutego 1945.
} 
minęły dwa lata. $Z$ ich tonu możemy wywnioskować, że w tym czasie relacja ojca i córki ożyła i rozkwitła na nowo. Zanim jednak powrócimy do szczegółowego omówienia tego zbioru, przytoczmy list — jedyny zachowany — Zofii Hertz do ojca.

Z korespondencji, kierowanej z Maisons-Laffitte do Łodzi, pozostał, jak już wiemy, zaledwie ślad. Zachował się jedynie list z 28 października 1955 roku $^{15}$; znając treść tegoż oraz drugiego, stanowiącego odpowiedź (z 20 listopada 1955 roku), a także ogólny kontekst, można w sposób przybliżony zarysować, jak wyglądała relacja ze strony podparyskiej korespondentki.

Wnioskujemy, że Zofia Hertz otoczyła po wojnie swego ojca troską i wsparciem, dbała o jego sprawy na tyle, na ile to było możliwe, zważywszy nie tylko okoliczności polityczne, ale też dzielącą ich odległość. W liście, jak można się spodziewać, nie porusza się wątków i tematów, którymi któraś ze stron mogłaby narazić się cenzurze, natomiast dowiadujemy się z niego o panującej w Paryżu, jesienią 1955 roku, epidemii grypy, która dosłownie „położyła” wszystkich domowników Instytutu Literackiego. Stąd - tłumaczy w liście Zofia Hertz - przeszło miesięczna przerwa w korespondencji. Brak systematyczności w wymianie korespondencji często powodowany był także pocztowymi opóźnieniami, dotyczyło to nawet przesyłek wysyłanych drogą lotniczą. W omawianym liście (choć pewnie było to regułą właściwą dla tej korespondencji) Zofia wyrażała swoje zaniepokojenie niezbyt dobrym stanem zdrowia ojca. Faktycznie, Ludwik miewał problemy ze zbyt wysokim ciśnieniem krwi, z sercem, a z wiekiem doszły do tego także dolegliwości, związane z chodzeniem i oddychaniem. Zatroskana ojcowskim stanem zdrowia, mając na uwadze jego poważny wiek (Ludwik miał wówczas prawie 70 lat), namawiała go, by podjął decyzję o przejściu na emeryturę i zadbał o własne zdrowie. Zdawała sobie sprawę, że podjęcie tego kroku wiąże się z mniejszymi poborami (uposażenie spadłoby do $60 \% \mathrm{w}$ stosunku do dotychczasowego), dlatego, co podkreślała kilka razy, oferowała mu pomoc finansową.

Martwię się natomiast bardzo Twoim stanem zdrowia. Naprawę uważam, że powinieneś przestać już pracować [...] w Twoim wieku trzeba się szanować [...] wierz mi, że gdybym mogła to bym $\mathrm{Ci}$ o wiele więcej wysyłała ${ }^{16}$.

W omawianym liście Zofia zastanawiała się, jakiego typu artykuły użytkowe, łatwo dostępne we Francji, a stanowiące towar deficytowy w Polsce, mogłaby posyłać, by ojciec wraz z Leosią (tak bliscy zwracali się do Eleonory Neuding) znaleźli rynek zbytu i uzyskali korzystną zapłatę. Rozważała więc wysyłanie wełny, na którą - co do czego nie miała wątpliwości — z pewnością można by znaleźć chętnych w Łodzi, mieście, które było zagłębiem przemysłu włókienniczego; kawy, o którą było wówczas trudno w Polsce, oraz leków, z dostępnością do których również nie było łatwo. W liście nadmieniała o wysyłce tkaniny, przeznaczonej, jak można przypuszczać, „na handel", oraz zielonej kawy z Afryki, którą sama otrzymała w prezencie. Zofia Hertz ubolewała jednocześnie nad tym, że okoliczności nie pozwalają jej na udzielenie pomocy finansowej ojcu w takim wymiarze, w jakim by tego od siebie oczekiwała. Czytamy:

[...] Francja jest krajem bardzo drogim, obecnie najdroższym w Europie, a zarobki są małe i bardzo o nie trudno. Jeśli idzie o nas to naprawdę ciężko pracując zarabiamy

${ }^{15}$ AIL 04, list z 28 października; list bez daty rocznej; w postscriptum przywołany został wątek „ostatnio odbywającego się" Festiwalu Młodzieży w Warszawie, który miał miejsce w lipcu-sierpniu 1955 roku, stąd przypuszczenie, że powinno datować się go na rok 1955, odpowiedź ojca z 20 listopada 1955 roku dodatkowo potwierdza to przypuszczenie.

16 Tamże. 
właściwie na porządne mieszkanie i jedzenie oraz papierosy, przejazdy i drobne wydatki, jak reperacja butów, pończochy, fryzjer (raz na dwa miesiące jeśli idzie o mnie), już kino czy teatr jest wydatkiem i dlatego prawie wcale nie chodzimy, a to że jesteśmy jako tako ubrani to naprawdę fuksem i przemyślnością, bo inaczej nie dalibyśmy rady ${ }^{17}$.

Zofia deklarowała jednocześnie, że gotowa jest uczynić wszystko, by ojciec mógł przejść na emeryturę i u schyłku życia wieść spokojny żywot. Paczki jednak słała nie tylko ona. Ludwik, wystarawszy się o zgodę w Ministerstwie Handlu Zagranicznego, wysłał do Francji, na prośbę córki, nasiona koperku. Za sprawą Zofii Hertz polski koperek został rozpropagowany w Maisons-Laffitte, a francuscy znajomi polskiej emigrantki mieli okazję poznać jeden z sekretów polskiej kuchni.

W dołączonym do listu postscriptum Zofia Hertz zdradza, że spotyka się i rozmawia z Polakami, którzy „dość często” przyjeżdżają do Paryża. Daje wyraz temu, że doskonale poinformowana jest o sytuacji $\mathrm{w}$ kraju - nie tylko z gazet, ale właśnie $\mathrm{z}$ pierwszej ręki. Jak wiadomo, na przełomie lat 40. i 50. Instytut Literacki w Maisons-Laffitte zaczął budować swoją renomę jako ośrodek niezwykle gościnny dla osób przyjeżdżających z kraju. Cieszył się przez to niesłabnąca popularnością i zaufaniem. Wizyty te nasiliły się po październikowej odwilży. Podparyskie miasteczko odwiedzili wówczas m.in. współzałożyciele Studenckiego Teatru Satyryków - Agnieszka Osiecka (podczas pierwszej, krótkiej wizyty w 1957 roku przywiozła maszynopis Cmentarzy Hłasko) i Jarosław AbramowNewerly, ponadto Roman Polański, Marek Hłasko, Leszek Kołakowski, Witold Jedlicki $\mathrm{i}$ in. Na początku lat 50. mieszkał tam Czesław Miłosz, który po krótkim „romansie” z władzami komunistycznymi powiedział głośne „Nie” nadwiślańskiemu reżimowi. W 1953 roku nakładem podparyskiej oficyny ukazał się jego Zniewolony umyst. Redaktor Jerzy Giedroyc widział drzemiącą w literaturze siłę emigracji, drukował więc $\mathrm{z}$ entuzjazmem prace m.in.: Czesława Straszewicza (Urugwaj), Jerzego Stempowskiego (Niemcy), Witolda Gombrowicza (Argentyna) czy Gustawa Herlinga-Grudzińskiego (Włochy). Środowisko paryskiej „Kultury” skupiało i wspierało wielu pisarzy emigracyjnych, jednak rzeczywistym celem działalności Giedroycia i jego współpracowników było faktyczne wywieranie wpływu na sytuację w kraju, m.in. poprzez drukowanie dzieł pisarzy krajowych, którzy często, także nieumyślnie, wikłali się w różnego typu zależności od władz PRL. Utwory krajowe Instytut Literacki zaczął wydawać w latach 50. Cykl ten zainaugurowały wspomniane wyżej Cmentarze Marka Hłasko oraz $W$ polu Stanisława Rembeka. Pisarze krajowi zyskali również szansę publikowania na łamach miesięcznika „Kultura”. Wielu z nich widziało w Jerzym Giedroyciu jedynego naprawdę niezależnego i godnego zaufania wydawcę. W 1961 roku do Maisons-Laffitte przyjechał Andrzej Stawar, związany przez lata z reżimem i przez wielu nazywany ,,pisarzem-komunistą”. Nakładem Instytutu ukazały się jego Pisma ostatnie, był to wyraźny sygnał dla władzy ludowej. Tym między innymi posunięciem podparyskie wydawnictwo zyskało sobie status niezależnej i wolnej polskiej instytucji. Zdarzało się, że pisarze, drukujący w paryskiej „Kulturze”, oskarżani byli wręcz o antysowieckość, jak np. Stanisław Rembek, i często dla ratowania swej pozycji w kraju składali oświadczenia, że wydanie nastąpiło bez ich wyraźnej woli i zgody. Trzeba też dodać, że redakcja „Kultury” ustanowiła stypendia dla studentów z kraju, a przyjezdni zawsze mogli liczyć na mieszkanie w siedzibie „Kultury” ${ }^{18}$. Nie ulega najmniejszej wątpliwości, że mieszkańcy Maisons-Laffitte interesowali się bieżącą sytuacją w kraju. Pozostaje postawić pytanie: czy ojciec Zofii Hertz już wtedy zdawał sobie sprawę z tego, jak istotną rolę odgrywa instytucja, z którą związała swoje życie jego córka?

\footnotetext{
${ }^{17}$ Tamże.

${ }^{18}$ A. S. Kowalczyk, Giedroyc i ,Kultura”, Wrocław 1999, s. 167-195, s. 197-225.
} 
W zbiorze listów Ludwika Neudinga do córki nie odnajdujemy informacji o działalności Instytutu Literackiego w Maisons-Laffitte czy o roli, jaką pełniła w tym przedsięwzięciu Zofia Hertz. Przyczyn można się domyślać. W korespondencji zostają jedynie zasygnalizowane pewne fakty z życia codziennego, takie jak: epidemia grypy, problemy mieszkaniowe ${ }^{19}$ czy brak wytchnienia i ciągłe zapracowanie Zofii. Ludwik nie zdawał sobie sprawy z tego, czym w istocie zajmuje się jego córka, wiedział jedynie, że jest to branża, powiemy dziś, medialna, i namawiał ją do zmiany profesji:

W dziennikarstwie jest dużo pracy i zdaje mi się, że to jest praca nie bardzo opłacalna? Czy w Paryżu nie można osiągnąć jakiegoś handlowego zastępstwa lub intratnej posady abyś mogła wraz z Zygmuntem powrócić do pracy handlowej — co przyniosłoby więcej korzyści, a mniej by absorbowało czasu i sił ${ }^{20}$

lub w innym miejscu:

Czy nie dałoby się w Paryżu znaleźć pracy w waszym zawodzie - wszak Zygmunt jest zdolnym handlowcem i w tym dziale wielu ludzi poszukują i sądzę, że z większym zamiłowaniem pracuje się w swoim zawodzie i osiąga się większe rezultaty ${ }^{21}$.

Znowu w innym miejscu daje wyraz swojego niedoinformowania w sprawie funkcjonowania podparyskiej instytucji:

Zadziwia mnie Wasza biblioteka, wynosi około 10000 tomów - do czego tyle egzemplarzy potrzeba? - czy prowadzicie jakieś dziennikarstwo czy inne przedsiębiorstwo w tym zakresie ${ }^{22}$.

Martwił go także nadmiar pracy, z jakim borykała się Zofia Hertz; pisze z troską:

Martwi mnie tylko, że Ty musisz tyle sama pracować - czy nie masz w swym dziale jakiejś pomocy, aby w pracy swej uzyskać pewne odprężenie ${ }^{23}$.

Z pewnością z każdym kolejnym rokiem dochodziły do niego jakieś informacje, choćby te o istnieniu emigracyjnego miesięcznika „Kultura” i jego charakterze, może nawet miał okazję zapoznać się z którymś z numerów. Tego jednak niestety nie jesteśmy w stanie potwierdzić. Można się spodziewać, że jego wiedza w tym zakresie została wzbogacona za sprawą wizyty Agnieszki Osieckiej, która zawitała do jego łódzkiego mieszkania, aby w imieniu Zofii Hertz przekazać paczki z żywnością i ubraniami. W jednym z listów czytamy:

W przyszłym tygodniu [Osiecka] nas ponownie odwiedzi i [...] opowie nam bliższe szczegóły o was — gdyż przy pierwszej wizycie była z kolegą i się b. spieszyli ${ }^{24}$.

19 Zespół „Kultury” został zmuszony do znalezienia nowego lokum, gdy właściciel willi przy avenue Corneille wbrew umowie najmu podniósł bezceremonialnie czynsz o $20 \%$. Spór zakończył się w sądzie, bez pomyślnego skutku dla strony poszkodowanej. W grudniu 1954 roku dzięki wsparciu przyjaciół i czytelników, zakupiono dom przy avenue de Poissy (merostwo Le Mesnil-le-Roi, a nie jak powszechnie się uważa Maisons-Laffitte), który stał się nową siedzibą Instytutu Literackiego.

${ }^{20}$ AIL 04, list Ludwika Neudinga do Zofii Hertz z 15 grudnia 1948.

${ }^{21}$ AIL 04, list Ludwika Neudinga do Zofii Hertz z 15 kwietnia 1949.

${ }^{22}$ AIL 04, list Ludwika Neudinga do Zofii Hertz z 8 marca 1955.

${ }^{23}$ AIL 04, list Ludwika Neudinga do Zofii Hertz z 17 stycznia 1952.

${ }^{24}$ AIL 04, list Ludwika Neudinga do Zofii Hertz z 9 grudnia 1957. 
Wiemy też, że Ludwika Neudinga odwiedzali z polecenia Zofii Hertz i inni goście. Nie wymieniał ich jednak, przypuszczalnie dla bezpieczeństwa, z imienia i nazwiska, używając określeń w rodzaju: „Twój znajomy z Warszawy”, „Twoja znajoma z Warszawy”, czy „,znajoma z Berlina”. W 1957 roku Neuding zdaje się już bardziej zorientowany w specyfice działalności Instytutu Literackiego, czemu daje wyraz w jednym z listów z tego czasu:

Wyobrażam sobie jak Ty musisz być zajęta - gdy was ciągle tyle osób odwiedza — ale w każdym razie masz pewną przyjemność i wiadomości z kraju ${ }^{25}$.

Domyślamy się, dlaczego Zofia Hertz nie chciała wtajemniczać swojego ojca w prowadzoną przez Instytut Literacki działalność wydawniczą - wiedza taka niewiele by mu dała w codziennej egzystencji, a z pewnością mógłby stracić w oczach władz krajowych. W Polsce dokładano wszelkich starań, by zwalczanie paryskiego ośrodka było jak najbardziej skuteczne ${ }^{26}$, a stanowią o tym chociażby próby zwerbowania Zygmunta Hertza przez Służbę Bezpieczeństwa PRL. Sprawie tej Monika Sędłak poświęciła jeden $\mathrm{z}$ rozdziałów w swojej dysertacji doktorskiej ${ }^{27}$, a tropy na temat inwigilacji mieszkańców Maisons-Laffitte przez służby reżimu komunistycznego znaleźć dziś możemy w obfitym zbiorze dokumentów archiwalnych, przechowywanych w Instytucie Pamięci Narodowej. Wymiana takich informacji mogłaby narazić przede wszystkim korespondencję Zofii i Ludwika, a tego z pewnością nie chciała żadna ze stron.

Ojciec z bólem znosił rozłąkę z córką i przez te wszystkie lata marzył o tym, żeby się z Zofią spotkać, i to mimo barier, jakimi były brak paszportu czy problem z uzyskaniem zezwolenia na wyjazd zagraniczny. Ludwik Neuding wielokrotnie dawał w listach wyraz swojej tęsknocie, nie ukrywając wzruszenia i smutku, że on, jako ojciec, w zaistniałej sytuacji nie może okazać pomocy córce, poza słownym wsparciem i otuchą:

Nad wyraz mi przykro, że czasy tak się złożyły, że nie możemy się widzieć — już upływa 13 lat, jak Cię po raz ostatni widziałem i kto wie kiedy Cię zobaczę. Czas ucieka, a dla mnie to już dużo nie pozostało - więc nie wiem czy będzie mi sądzone z Tobą się zobaczyć - a bardzo bym chciał, aby ta chwila nadeszła ${ }^{28}$

czy gdzie indziej:

Naprawdę już mija 15 lat jak Ciebie nie widziałem — bardzo mi smutno z tego powodu — przy zobaczeniu się moglibyśmy sobie wiele opowiedzieć za ten okres czasu — czy jeszcze kiedyś się zobaczymy? ${ }^{29}$

Bardzo bym chciał na schyłku życia jeszcze się z Tobą zobaczyćc ${ }^{30}$.

Jedno mi tylko przykro, że po tylu letniej rozłące — zapewne Pan Bóg nie da mi już doczekać Ciebie zobaczyć i uściskać - a zarazem podziękować za wszystko dla nas dotąd uczynione ${ }^{31}$.

${ }^{25}$ AIL 04, list Ludwika Neudinga do Zofii Hertz z 10 maja 1957.

${ }^{26}$ Zob.: M. Tyrchan, Paryska ,Kultura” wobec konfliktów politycznych w Polsce (19761989), Poznań 2011; B. Kaliski, Kurierzy wolnego słowa (Paryż-Praga-Warszawa, 1968-1970), Warszawa 2014.

${ }^{27}$ M. Sędłak, „Zygmunt Hertz w środowisku paryskiej «Kultury». Próba biografii”, mps., Lublin 2007.

${ }^{28}$ AIL 04, list Ludwika Neudinga do Zofii Hertz z 19 lutego 1953.

${ }^{29}$ AIL 04, list Ludwika Neudinga do Zofii Hertz z 9 maja 1954.

${ }^{30}$ AIL 04, list Ludwika Neudinga do Zofii Hertz z 10 lipca 1949.

${ }^{31}$ AIL 04, list Ludwika Neudinga do Zofii Hertz z marca 1956; list bez daty dziennej. 
Rozważał trudności w spełnianiu wymogów formalnych podczas starania się o zezwolenie na wyjazd:

Będą jednak bardzo wielkie trudności w otrzymaniu zezwolenia na wyjazd i sądzę, że usilne me zabiegi w tym kierunku spełzną na niczym. Byłaby to dla mnie olbrzymia frajda zobaczenia się z $\mathrm{Wami}^{32}$.

Rodzina i znajomi w kraju usilnie namawiali go, aby spotkał się z córką po latach:

Wszyscy mnie tu namawiają, że powinienem obecnie skorzystać z możliwości i wybrać się do Ciebie w odwiedziny. - Ja bardzo chętnie bym to uczynił — aby z Tobą po 17 latach się zobaczyć - lecz w mym sędziwym wieku - obawiam się puszczenia $\mathrm{w}$ tak daleką podróż — żebym był o 5-10 lat młodszy — to bez namysłu bym do was na krótki czas zawital ${ }^{33}$.

W omawianym zbiorze listów z rzadka podnoszona jest tematyka rodzinna. Bywało, że Ludwik Neuding w miarę możliwości i wiedzy, jaką posiadał, starał się zrelacjonować córce losy krewnych, którzy przeżyli wojnę. Ubolewał nad tym, że z licznej rodziny pozostała tylko garstka, składająca się ledwie z 3-4 osób. Żalił się w listach:

Ze starych znajomych, jak również członków naszej rodziny nikogo nie spotykam nawet będąc w Warszawie trudno kogoś odnaleźć — widocznie [...] wszyscy znikli. Przykro mi, że wy również jesteście tak oddaleni ${ }^{34}$.

Albo w innym miejscu: „Cała linia Neudingów wymarła, ja jeden z starej generacji pozostałem" 35 . Z listów ojca Zofii Hertz dowiadujemy się także, iż Ludwik wraz z Eleonorą dzielili mieszkanie z Edwardem (Neudingiem?) i jego żoną Zofią:

Mieszkamy razem [...] mamy po 2 pokoje i wspólną kuchnie — żyjemy w zgodzie a to najważniejsze $\mathrm{e}^{36}$.

Razem ze współlokatorami spędzali święta i inne rodzinne uroczystości, dodawali sobie otuchy w dźwiganiu ciężarów dnia codziennego, jednak mimo „wspólnego dachu” prowadzili osobne gospodarstwa. Trudno tu bliżej określić stopień pokrewieństwa, kwestia ta nie została jednoznacznie zaznaczona w listach, nie pada również nazwisko.

W listach Ludwika do Zofii wzmiankowany jest również Wacław Sterner, pochodzący z gałęzi rodziny, mieszkającej w Warszawie (syn Józefa Sternera i Heleny z Neudingów, prawdopodobnie siostrzeniec Ludwika). Jego nazwisko figuruje w Polskim Stowniku Biograficznym. Był wicedyrektorem Warszawskiej Dyrekcji Odbudowy i wraz z żoną Zofią (z d. Domańską) i córką Barbarą mieszkali w Warszawie ${ }^{37}$. Ludwik wspomina również o rodzinie, która wyemigrowała po wojnie do Rio de Janeiro - Stefan Neuding (kuzyn Zofii Hertz w drugiej linii), Adolf Neuding, ojciec Stefana (kuzyn Ludwika Neudina w pierwszej linii) — ojcowie Adolfa i Ludwika byli rodzonymi braćmi. Wspomniana została również Ewa Deker (z d. Neuding), siostra Adolfa. Z kolei brat Stefana, Tadeusz Neuding, wyemigrował z żoną do Palestyny — o czym dowiadujemy się z relacji Ludwika. Omawiane listy to z pewnością jedno z niewielu źródeł informacji na temat bliższej i dalszej

\footnotetext{
32 AIL 04, list Ludwika Neudinga do Zofii Hertz z 13 maja 1950.

${ }^{33}$ AIL 04, list Ludwika Neudinga do Zofii Hertz z 8 grudnia 1956.

${ }^{34}$ AIL 04, list Ludwika Neudinga do Zofii Hertz z 12 czerwca 1955.

${ }^{35}$ AIL 04, list Ludwika Neudinga do Zofii Hertz z 6 października 1954.

${ }^{36}$ AIL 04, list Ludwika Neudinga do Zofii Hertz z 12 maja 1951.

${ }^{37}$ Zob.: Wacław Sterner, [hasło w:] Internetowy Polski Stownik Biograficzny, www.ipsb. nina.gov.pl. (dostęp: marzec 2016).
} 
rodziny Zofii Hertz. Jeśli zaś chodzi o rodzinę Eleonory Neuding, Ludwik wymienia Julię, siostrę Leosi, zamieszkałą najpierw w Jeleniej Górze, a później w Olsztynie, do której przy każdej możliwej okazji małżonkowie jeździli z wizytą, by odpoczać od Łodzi. Wszystkie z zasugerowanych tu powyżej tropów można i należałoby prześledzić bardziej szczegółowo, jednak nie stanowi to tematu niniejszego artykułu.

Kolejnym, wymagającym przybliżenia problemem, poruszanym w listach Ludwika Neudinga do Zofii Hertz, jest systematycznie pogarszający się stan jego zdrowia. Praca w księgowości nad wyraz wyczerpywała i męczyła Ludwika, głównym powodem był zaawansowany wiek i towarzyszące temu dolegliwości. Od lutego 1952 roku zaczął się skarżyć córce na rosnące $\mathrm{z}$ dnia na dzień zmęczenie i brak sił. Lekarz zdiagnozował u niego zbyt wysokie ciśnienie i zaordynował zabieg upustu krwi. Na jakiś czas Ludwik odzyskał kondycję, wciąż jednak uskarżał się na brak sił i apetytu. Komisja lekarska zaleciła mu zażywanie leków na wzmocnienie. Od tego momentu Zofia Hertz zaczęła wysyłać ojcu preparaty, mające przysłużyć się ustabilizowaniu ciśnienia krwi, oraz suplementy witaminowe. Ojciec, bardzo wdzięczny za pomoc uzyskaną od córki, pisał: „Niezmiernie Ci dziękuje, za tak troskliwe zajęcie się mą chorobą. - Nadesłane mi lekarstwa i 4 paczki oliwek otrzymałem w należytym porządku" ${ }^{38}$. Zły stan zdrowia skutkował pięciotygodniowym urlopem w pracy. Proces leczenia wymagał dodatkowych nakładów finansowych na zakup zastrzyków z jodu, strzykawek i innych medykamentów, dlatego Ludwik nieśmiało wysuwał prośby o kolejne przesyłki z Paryża:

Gdybyś bez uszczerbku dla Ciebie chciała mi jeszcze podczas mej choroby pomóc, to może byś nam przysłała w przesyłce pocztowej $1 \frac{1}{2} \mathrm{~kg}$ pieprzu, $1 / 2 \mathrm{~kg}$ kakao i $1 / 2 \mathrm{~kg}$ kawy, tych artykułów tu brak i przy sprzedaży otrzymać można odpowiednią sumę ${ }^{39}$.

Ojciec relacjonował Zofii przebieg leczenia i dzielił się z nią zaleceniami, jakie otrzymywał od lekarzy:

drażetki Tensopan [...] przyjmuję też codziennie po 1 zastrzyku jodowym. - Stan mego serca się poprawił i ciśnienie krwi się zniżyło do 210, a początkowo miałem 290, co groziło już katastrofą ${ }^{40}$.

W czerwcu 1952 roku zdrowie Ludwika Neudinga znacznie się poprawiło. Mimo znacznego spadku wagi (aż dziesięć kilogramów), jaka nastąpiła w wyniku choroby, poczuł się o wiele silniejszy. Powrócił tak do pracy, jak i względnej formy. Zofia Hertz nieprzerwanie wysyłała leki i witaminy, za które Ludwik okazywał w listach wdzięczność, oraz inne artykuły użytkowe, które w jakiejś części sprzedawali (z Eleonorą). Naddatki leków, jak się dowiadujemy, Neudingowie zbywali w aptece za korzystną zapłatą. O ile Ludwik starał się być powściągliwy w wysuwaniu kolejnych próśb o przesyłki, o tyle jego żona Eleonora była dużo bardziej zdecydowana w wysuwaniu nowych życzeń:

mówię Ci szczerze, gdyby nie twa pomoc, za którą Ci mocno i serdecznie dziękuję to byłaby katastrofa, czyli ojciec nie mógłby mieć to, co ma [...] do każdej paczki 1 szt. [pomadki] możesz dorzucić, kawa, kakao, zawsze jest aktualne i z łatwością można sprzedać. [...] wszystko nowe, stare można sprzedać. [...] wełnę czerwoną już otrzymałam. [...] Zosiu, na razie przysyłaj wełnę tylko jaskrawe kolory, a dalej się zobaczy ${ }^{41}$.

\footnotetext{
${ }^{38}$ AIL 04, list Ludwika Neudinga do Zofii Hertz z 29 kwietnia 1952.

${ }^{39}$ Tamże.

${ }^{40}$ AIL 04, list Ludwika Neudinga do Zofii Hertz z 20 maja 1952.

${ }^{41}$ AIL 04, list Eleonory Neuding z 23 stycznia 1953.
} 
Latem 1953 roku stan zdrowia Ludwika Neudinga znowu się pogorszył. Powróciły problemy kardiologiczne, pojawiły się duszności, uniemożliwiające nieraz zasypianie. Ojciec na bieżąco pisał córce o swoim pogarszającym się samopoczuciu, jednak nie zawsze chciał przyznawać się do wszystkich swoich dolegliwości i słabości. Z pomocą wówczas przychodziła Eleonora, która dopisywała do jego listów wiadomość dla Zofii:

Zosiu! Ojca zdrowie wisi na włosku, nogi puchną [...] jak banie. [...] jak będziesz pisać do ojca, nic nie wspominaj, że ja Ci pisałam jaki jest $\operatorname{stan}^{42}$.

Zdrowie Ludwika, znowu dzięki lekom, wróciło na jakiś czas do normy. Jesienią 1954 roku zmienił pracę na lżejszą, niewymagającą dużej odpowiedzialności. Nie było to stanowisko kierownicze, Ludwik jednak nie sprecyzował, czym zajmował się po powrocie do zdrowia.

W grudniu 1954 roku Ludwik Neuding zachorował na grypę, która skończyła się ciężkim zapaleniem płuc. Przeczuwał, że nadszedł czas, by w listach pożegnać z córką, gdyż jego koniec jest już bliski:

W ciężkich chwilach ciągle myślałem o Tobie, że nie mogę z Tobą się pożegnać i serdecznie Ci podziękować za wszystko dla mnie uczynione. - Nie martw się Zosiu w moich latach w każdej chwili na smutną wiadomość musisz być przygotowana ${ }^{43}$.

Ojciec zdradzał swoje wyrzuty sumienia, które budził w nim fakt nieustającej pomocy ze strony córki:

Przykro mi bardzo, że ciągle Ci sprawiam kłopoty mą osobą - a ja nawet w małej części nie mogę Ci się odwdzięczyćc $\dot{c}^{44}$.

W marcu 1956 roku, jak pisał, zdiagnozowano u niego rozedmę płuc. Dowiadujemy się, że lekarze namawiali go, aby porzucił pracę i przeszedł na emeryturę, jednak Ludwikowi trudno było wyobrazić sobie odstąpienie od codziennych obowiązków tak ze względów finansowych, jak i towarzyskich.

Zofia Hertz udzielała pomocy nie tylko swemu ojcu i jego żonie Eleonorze, ale także ludziom z ich bliskiego otoczenia, m.in. przełożonemu Ludwika, który chorował na cukrzycę. W przesyłkach załączała, zakupione dla niego we Francji, pastylki na tę dolegliwość. Ostatni z nadesłanych listów datowany jest na 6 stycznia 1958 roku. Ludwik dziękuje w nim za życzenia świąteczne i noworoczne, wysłane do Łodzi przez Zofię i Zygmunta Hertzów. Z pewnością ku radości córki, Ludwik informował:

Zdrowie mi jakoś dopisuje - samopoczucie mam dobre. Pracuję jak zwykle. Zima u nas jest jak dotąd dość lekka, co na moje zdrowie dobrze wpływa ${ }^{45}$.

Nic nie wskazywało na to, że będzie to ostatni list, jaki Ludwik Neuding wysłał do córki. Niespełna dziesięć dni później zmarł. Pogrzeb odbył się 20 stycznia 1958 roku w Łodzi, w kaplicy Starego Cmentarza Katolickiego przy ul. Ogrodowej.

Śmierć Ludwika Neudinga, kładąc kres korespondencji Zofii z ojcem, stała się jednocześnie impulsem do stałej wymiany listów emigrantki z Eleonorą; korespondencja trwała od 1958 do 1968 roku. Pierwszy z zachowanych listów datowany jest na 15 lutego 1958 roku, Leosia relacjonuje w nim przebieg choroby swego męża, Ludwika, tymi słowy:

\footnotetext{
${ }^{42}$ AIL 04, list Ludwika Neudinga z 16 sierpnia 1953.

43 AIL 04, list Ludwika Neudinga do Zofii Hertz z 4 grudnia 1954.

${ }^{44}$ AIL 04, list Ludwika Neudinga do Zofii Hertz z 29 czerwca 1955.

${ }^{45}$ AIL 04, list Ludwika Neudinga do Zofii Hertz z 6 stycznia 1958.
} 
Zaczęło się od poniedziałku, to było 13 stycznia [...] doktór przyszedł, obadał go, dał mu dwa zastrzyki, i mówi, że serce jest w gorszym stanie niż było ostatnio [...] W nocy się budzę, słyszę mocne chrapanie, lecę do niego, a on nieprzytomny, budzę Edka, on prędko pogotowie prywatne, przyjeżdża doktor, konstatuje zawał serca i daje zastrzyk i opiniuje do szpitala. [...] W piątek ubierałam się do szpitala wtem dostaję wiadomość ażeby przyjść bo stan jest bardzo ciężki [...] do końca przytomności nie odzyskał. [...] w poniedziałek był pochowany ${ }^{46}$.

W dniu śmierci Ludwika wspomniany już wcześniej Edward (krewny, z którym Neudingowie mieszkali) nadał depeszę do Zofii Hertz z informacją o śmierci jej ojca. Jednak, jak się okazało, wiadomość do Zofii nie dotarła. Mieszkanka Maisons-Laffitte dowiedziała się o śmierci swojego ojca dopiero po pogrzebie. Między korespondentkami doszło na tym tle do ostrej wymiany zdań. Zofia, jak można przypuszczać (nie dysponujemy bowiem listami adresowanymi do Eleonory), zarzucała macosze brak informacji o śmierci ojca. W liście do Zofii Hertz wdowa pisała:

jak możesz przeciwko mnie występować tak agresywnie, w parę godzin po zgonie, wysłałam do wszystkich depeszę, jak również i do Ciebie, a że poczta nie doręczyła, czy to moja wina ${ }^{47}$.

Z tonu kolejnych listów można wywnioskować, że konflikt został zażegnany. Sytuacja wyjaśniła się wiele miesięcy później, kiedy wyszło na jaw, że depesza, owszem, została doręczona, ale nie Zofii Hertz, a Zygmuntowi. Nie jest jasne, dlaczego Zygmunt zataił tę informację przed swoją małżonką ${ }^{48}$.

Po śmierci Ludwika sytuacja finansowa Eleonory pogorszyła się, a w każdym razie tak przedstawiała to w listach do Zofii Hertz. Donosiła, że wszystkie oszczędności, które zdołali zgromadzić, musiała wydać na pogrzeb. Czyniła starania o uzyskanie emerytury po mężu, jednak, gdy już ją otrzymała, wysokość, w jej odczuciu, okazała się niewystarczająca na pokrycie podstawowych potrzeb. $Z$ pomocą przychodziła Zofia Hertz, która wysyłała Eleonorze pieniądze, ubrania i artykuły spożywcze. Eleonora na każdym niemal kroku okazywała swoją wdzięczność, trzeba jednak przyznać, że w wysuwaniu kolejnych próśb była nader śmiała:

Jeśli mam być szczera to wolałabym w gotówce, jeśli Ci to sprawia trudność to ja się zadowolę tym, co przyślesz ${ }^{49}$

czy w innym miejscu:

Zosiu może masz jakieś niepotrzebne zimowe palto, to które od Ciebie dostałam przed ośmioma laty jest bardzo sfatygowane, na niepogody to jeszcze można w nim chodzić, a żeby jako tako wiesz wyglądać to wykluczone. Jeśli chodzi o kolor to wolałabym czarne $^{50}$.

W 1959 roku Eleonora podjęła pracę zarobkową, można przypuszczać, że powodem takiej decyzji była chęć finansowego uniezależnienia się od Zofii Hertz. Zajmowała się szyciem chusteczek i planowała poszerzenie swej chałupniczej działalności o zakup maszyny do szycia rękawiczek.

${ }^{46}$ AIL 05, list Eleonory Neuding do Zofii Hertz z 15 lutego 1958.

${ }^{47}$ AIL 05, list Eleonory Neuding do Zofii Hertz z 25 lutego 1958.

48 AIL 05, listy Eleonory Neuding do Zofii Hertz z: 15 lutego 1958, 25 lutego 1958 i 17 września 1958.

${ }^{49}$ AIL 05, list Eleonory Neuding do Zofii Herz z 26 marca 1958.

${ }^{50}$ AIL 05, list Eleonory Neuding do Zofii Hertz z 4 października 1968. 
Poważne problemy ze zdrowiem Eleonory zaczęły się w połowie lat 60; chorowała na wątrobę, serce oraz pogłębiającą się nerwicę. $W$ jednym $\mathrm{z}$ ostatnich listów pisała:

Bardzo dziękuję za paczkę. Jeszcze dokładnie nie przeglądam, nie mam na to siły i piszę w łóżku. Jest trochę lepiej, ręka mi się trzęsie ${ }^{51}$.

Następny list, datowany na 20 listopada 1968 roku, był znacznie krótszy od poprzednich, co sugeruje, że stan jej zdrowia jeszcze się pogorszył. Potwierdzeniem tego faktu są słowa: „Dziś przychodzi doktór. Jeszcze jestem bardzo słaba, cała się trzęsę. Jeszcze raz za wszystko dziękuję"52. List ten okazał się pożegnaniem Eleonory z Zofią Hertz.

Z korespondencji Ludwika Neudinga i Eleonory Neuding z Zofią Hertz wynika jasno, że adresatka wspierała swoją najbliższą rodzinę wszystkimi dostępnymi środkami i sposobami. W każdym niemal liście Ludwik składał podziękowania albo za pieniądze, albo za przesyłki z ubraniami, albo za paczki żywnościowe, albo wreszcie za leki. Z roku na rok kwoty przesyłane z Paryża były coraz wyższe, paczki mieściły coraz więcej artykułów. Jakkolwiek Ludwik wyrażał troskę o kondycję finansową córki, zdając sobie sprawę, że powodzi się jej różnie, to jednak ani on, ani później Eleonora nie zaniechali próśb o kolejne artykuły. We wspomnianej wyżej ankiecie personalnej, w punkcie dotyczącym posiadania rodziny za granicą, Ludwik zdecydowanie zaprzeczył. Na uwagę zasługuje fakt, że Neuding w żadnym ze swoich listów nie daje podstaw ku temu, by przez ewentualne osoby trzecie adresatka listu mogłaby zostać uznana za córkę. Możemy przypuszczać, że chciał w ten sposób chronić i siebie, i Zofię. Dzięki temu ich korespondencja, mimo niesprzyjających okoliczności, mogła nieprzerwanie trwać przez ponad dekadę. Listy ukazują nam inne oblicze Zofii Hertz. Była, jak widać, nie tylko duchem opiekuńczym domu „Kultury” — czym zasłynęła tak wśród mieszkańców, jak i gości odwiedzających tę ważną emigracyjną instytucję - ale także swego domu rodzinnego, była dbającą, kochającą córką, zatroskaną o losy ojca i mieszkającej w kraju rodziny.

\section{LITERATURA:}

Archiwum Instytutu Literackiego w Maisons Laffitte

Korespondencja Eleonory Neuding z Zofią Hertz (1958-1968)

Korespondencja Ludwika Neudinga z Zofią Hertz (1945-1958)

Archiwum Krajowej Rady Spółdzielczej w Warszawie

Akta pracownicze Ludwika Neudinga

I. Chruślińska, Była raz Kultura ... Rozmowy z Zofia Hertz, Lublin 2003;

J. Giedroyc, Autobiografia na cztery rece, oprac. K. Pomian, Warszawa 1994;

H. M. Giza, Ostatnie lato w Maisons-Laffitte, Wrocław 2007;

Internetowy Polski Słownik Biograficzny: www.ipsb.nina.gov.pl;

B. Kaliski, Kurierzy wolnego słowa (Paryż-Praga-Warszawa, 1968-1970), Warszawa 2014;

A. S. Kowalczyk, Giedroyc i „Kultura”, Wrocław 1999;

A. Olszewska, Dokumenty Zofii Hertz (1910/1911-2003), „Zeszyty Historyczne” 2006 nr 156;

M. Sędłak, „Zygmunt Hertz w środowisku paryskiej «Kultury». Próba biografii”, mps. Lublin 2007 ;

M. Tyrchan, Paryska „Kultura wobec konfliktów politycznych w Polsce (1976-1989), Poznań 2011.

${ }^{51}$ AIL 05, list Eleonory Neuding do Zofii Hertz z 10 listopada 1968.

${ }^{52}$ AIL 05, list Eleonory Neuding do Zofii Hertz z 20 listopada 1968. 
ZOFIA HERTZ IN THE LIGHT OF HER CORRESPONDENCE WITH HER FATHER (1945-1958)

The article is a documentation and an interpretation of the correspondence between Zofia Hertz and her father Ludwik Neuding. The 111 letters written between 1945 and 1958 are a testament of great and "small" history, comprising biographical snippets of the co-founder of the Literary Institute. An introduction to an epistolographic presentation is the biography depicted in an abbreviated form: a difficult childhood and the separation from her motherland being a prelude to the first letter from her father which she received just after the war had ended. The presented material enables us to perceive Zofia not only as a woman creating a literary world in exile, but, most importantly, as a daughter, who despite having a complicated relationship with her father still supported him using all available means and ways. It is also- on the other hand-a testament of fatherly worries and "live coverage" from a country near, yet distant, which "liberated" Poland was for Zofia.

KEYWORDS: The Literary Institute; Kultura; father; Poland; help. 